Towards a conceptual model of the job performance of construction professionals: A person-environment fit perspective.

\title{
Bo Xiong
}

School of Civil Engineering and Built Environment

Queensland University of Technology (QUT)

Garden's Point

Brisbane Queensland

Australia

Email: peterxiongbobo@163.com

Sidney Newton

School of Built Environment

University of Technology Sydney

Sydney NSW

Australia

Email: sidney.newton@,uts.edu.au

Phone: +61 295143188

Martin Skitmore (corresponding author)

School of Civil Engineering and Built Environment

Queensland University of Technology (QUT)

Garden's Point

Brisbane Queensland 
Australia

Email: rm.skitmore@qut.edu.au

Phone: +61 738933170

ID: orcid.org/0000-0001-7135-1201

12 November 2018 


\section{Towards a Conceptual Model of the Job Performance of}

\section{Construction Professionals: A Person-Environment Fit}

\section{Perspective}

\section{Abstract}

The architecture, engineering, and construction (AEC) industry is well known for low productivity, with a critical obstacle being the difficulties associated with understanding the mechanism of job performance. This due to established theories being incapable of capturing and dealing with the complexities associated with construction projects, with extant performance studies falling short in the context of complex projects by not grounding the factors involved in a common conceptual model that articulates the mechanics of job performance.

In response, this study builds on person-environment (P-E) fit theory using a stimulusorganism-response paradigm, to develop a foundational conceptual model of the performance-related working behaviors of construction professionals. This study emphasizes the mediating role of P-E fit assessment and integrates key P-E relationships in a simplified framework, with a common layer based on P-E fit assessment factors that both accommodates previous studies and lays a coherent foundation for future studies. The model can also be applied in a reverse, diagnostic, capacity to identify corrective approaches and appropriate management strategies, and is easily adaptable to more general situations beyond the construction industry. 
Concluding remarks concern the major contributions made and prospects for future development.

Keywords: Job performance, person-environment fit, stimulus-organism-response, construction professionals.

\section{Introduction}

The Australian architecture, engineering, and construction (AEC) industry is characterized by increasing complexity and low productivity (Business and Enterprise Committee, 2008; Construction Task Force, 1998; Productivity Commission, 2014). Complexity arises significantly through the scope and variety of construction project work, its structure, and the dynamic nature of both client requirements and supply chain performance (Xia \& Chan, 2012), while the generally low productivity is clearly manifest and remains a resolutely intransigent impediment to project performance (Australian Constructors Association, 2014). The widely aware question is therefore How to improve construction project performance in the face of the burgeoning complexity of construction projects?

This has been previously addressed at different project stages - from inception (Huang \& Li, 2012) to whole-of-life (Park, 2009) - and at different levels of operation, from the individual worker (Ahadzie et al., 2008a) to the project overall (Busby \& Zhang, 2008). Numerous studies of individual job performance, for example, have also identified a series of significant influences, including working environment, individual personality, knowledge of the job, working experience, and psychological reactions (Leung et al., 2006, Pheng \& Chuan, 2006). 
However, a critical obstacle concerns the difficulties associated with the assessment of project performance, as established theories are incapable of capturing and dealing with the complexity associated with construction projects (Zhu \& Mostafavi, 2017). Moreover, while there are many studies of productivity evaluation models (e.g., Ibbs \& Vaughn, 2015; Thomas, 2015), project performance in general lacks a clear definition, consistent focus, and/or a comprehensive model (Scott-Young \& Samson, 2008; Svejvig \& Andersen, 2015; Wallace et al., 2004). Similarly, studies of individual performance fall short in the context of complex projects by not grounding the factors in a common conceptual model that articulates the mechanics of job performance. This is particularly significant, because such a model would enable the translation of performance measures into actionable management responses. The research gap, therefore, is the lack of a model linking individual job performance and the construction project environment.

The closest candidate is the person-environment (P-E) fit framework, often used in human resource management to predict and assess job performance (Schneider, 2001). Here, the term 'P-E fit' refers to congruence between the attributes of an individual and those of the environment (Schneider, Smith, \& Goldstein, 1992) - the underlying assumption being that such congruence will enable individuals and organizations to perform more effectively (Ostroff, 1993). Previous P-E fit studies of job performance specific to construction project professionals have identified a connection between their behaviors and direct psychological reaction to specific situations (Poon et al., 2013;Xiong et al., 2015a), predominantly by the application of regression analysis. However, the broader application of the P-E fit approach has been constrained by criticisms concerning the single direct measurement of discrepancies between, typically, incommensurate P and E constructs (Kristof, 1996; Schneider, 2001). In response, an approach using multiple indirect measures is now gaining credibility (Chuang et 
al., 2015): this comprises three extrinsic assessments of organisational commitment, work performance, and job satisfaction (Caplan, 1987).

In this study, we develop a modified P-E fit framework to assess the job performance of construction professionals based on the congruence between their personal characteristics and those required by a given project context, with different levels of P-E fit satisfying particular project demands, and P-E misfit accounting for such unwanted project outcomes as increased staff turnover. Work stress is substituted for Caplan's extrinsic work performance assessment, with a critical mediating layer also introduced between the stimulus and response concepts - effectively following Bandura's social learning theory in articulating P-E fit into providing a critical mediating link between job performance measurement and associated environmental stimulus and individual response factors.

The main contribution is a novel integrated model that, as well as contributing specifically to understanding the job outcomes of construction professionals, also provides a common conceptual model of job performance and its antecedents in general. A further outcome is the potential use of the model in proposing an effective research agenda for future job-performance studies.

The paper proceeds as follows: First, job performance is conceptualized and defined in terms of three key aspects of task performance, organisational citizen behavior, and counterproductive work behavior. A review is then provided of the limited studies and key findings specific to job performance in the context of construction project management. P-E fit theory is next examined in the context of job performance assessment and an overarching conceptual model is developed to integrate P-E fit assessment as a critical component of job performance measurement. Finally, a detailed discussion of the model is presented and its potential contribution in directing future research. 


\section{Literature review}

\section{P-E Fit Theory}

Researchers explore the relationships between people and environmental situations with holding the question of how they fit or misfit with one another (Follmer, 2016). Since Lewin's (1935) assertion long ago that behavior (B) is a function of the person (P) and environment $(\mathrm{E})$ in the general form: $\mathrm{B}=\mathrm{f}(\mathrm{P}, \mathrm{E})$, the concept of $\mathrm{P}-\mathrm{E}$ fit has become the dominant theory in various branches of psychology, including personnel selection, vocational psychology, and social psychology (Schneider, 2001). For example, its growing application to psychological and related studies in the 1980s as a result of a focus on the psychological illness caused by work stress (e.g., Caplan, 1987; Edwards, 1996; Edwards et al., 1998; Senaratne \& Rasagopalasingam, 2017; Xiong et al., 2015a); its emphasis in the selection of personnel, involving the assessment of the knowledge, skills, ability, and personality of an individual matched against a range of required criteria for a specific job; its use as a direct predictor of career success - recruiting individuals with a higher fit leading to a more satisfied workforce (Bretz \& Judge, 1994; Follmer, 2016); its influence on the willingness of an individual to join an organization and, by mediating key attitudes (including job satisfaction and organisational commitment), its criticality on turnover intention (Westerman \& Cyr, 2004); and its being influenced by a variety of long-term outcomes, including ongoing task performance and organisational citizen behavior, (Kristof, 1996).

The concept of P-E fit is multidimensional and with several refinements. Muchinsky \& Monahan (1987), for example, distinguish between supplementary and complementary P-E fit, where supplementary fit refers to a circumstance in which the characteristics of an individual match the existing characteristics of the environment. Based on the psychological paradigm 'similarity-attraction', it is common practice for people to compare their personal 
values and attitudes with the organisational climate and values of a company, and to prefer, and/or be more satisfied, to work with that organization (Kristof, 1996). The majority of previous studies adopting P-E fit, or its sub-themes (including person-organisational fit, person-person fit and person-group fit), focus on the supplementary nature of fit (Chuang et al., 2015). In contrast, complementary fit refers to a circumstance in which the characteristics of an individual represent something that is a deficiency in the characteristics of the environment (or vice versa) and is most often utilized in empirical studies of work performance (Kristof, 1996). Based on the psychological paradigm 'needs-fulfilment', it represents a more proactive comparison between personal and environmental characteristics (Kristof, 1996; Muchinsky \& Monahan, 1987). As Chuang et al. (2015: 482) comment, 'current themes of PE fit that follow the concept of complementary fit include demandsabilities (D-A) fit and needs-supplies (N-S) fit'. Darrow \& Behrend (2017) develop models to measure the overall P-E fit and fit of its sub-themes, and find that the formative construct of D-A fit, N-S fit, and supplementary fit is satisfactory.

A critical point of concern with P-E fit has always been in deciding which constructs to use in the measurement of $\mathrm{P}$ and $\mathrm{E}$. This concern is primarily because the findings vary quite markedly when different measuring methods are used (Spokane, 1987). Fundamentally, P-E fit is grounded in the theory of work adjustment and, on that basis, it has been argued that the most relevant measurement constructs require independent but commensurate measures of people (P) and environment (E) (Spokane, 1987).

Difference scores, such as the algebraic (X-Y), absolute (|X-Y|) and squared differences form $(\mathrm{X}-\mathrm{Y})^{2}$ have been used as direct measures in many studies, with the assumption that a low P and E discrepancy denotes a better outcome (Kristof, 1996; Rounds et al., 1987). However, direct measures face several criticisms, one of the most abiding of which is that independent measures of $\mathrm{P}$ and $\mathrm{E}$ can prove more difficult to articulate and contrast because 
the two constructs are then confounded (Kristof, 1996). Direct measures are also incompatible with the prevailing notion of behavior when defined as a constellation of $\mathrm{P}$ and $\mathrm{E}$ - the idea that $\mathrm{P}$ and $\mathrm{E}$ are interrelated and interdependent (Schneider, 2001).

Alternative modes of measurement are necessary when the assessment of $\mathrm{P}$ and $\mathrm{E}$ is made simultaneously across multiple dimensions of P-E fit. As highlighted by Kristof (1996), the measure of environment may have a stronger influence on personal variables (such as stress, satisfaction, and commitment) than it has directly on P-E fit itself. Since P-E fit is the implicit key to understanding human behavior (Schneider, 2001), identifying extrinsic measures of P-E fit is critical.

$<<$ insert Fig. 1 here $>>$

Based on Giauque et al. (2014), Kristof (1996) and others, therefore, Fig. 1 illustrates the principal elements of P-E fit and their associated forms of assessment. This shows that the elements of P-E fit relate between P and E in terms of needs and supplies, demands and abilities, and characteristics and attributes (supplementary fit). The associated forms of assessment are organisational commitment (to supplementary fit), work stress (to demandsabilities fit), and job satisfaction (for needs-supplies fit), as elaborated in the following subsections.

\section{Organisational Commitment}

The use of organisational commitment to assess supplementary fit is a relatively common practice and broadly held to be a measure of the acceptance and appreciation of organisational goals and values (Mowday et al., 1979). However, specific definitions vary considerably (Becker, 1960). In the current context, organisational commitment is specific to the related behavior of employees and characterized by (1) an acceptance and appreciation of 
the goals and values of the organization, (2) a willingness to contribute additional effort towards the success of the organization, and (3) a strong desire to remain with the organization (Mowday et al., 1979). A longitudinal study of the relationships between organisational commitment, job satisfaction, and staff turnover over time by Porter et al. (1974) revealed general attitudes indicating that organisational commitment is an important driver of the leave or stay decision. Accordingly, building organisational commitment needs to begin at the earliest possible stage of employment and can even be developed prior to entry into an organization (O'Reilly \& Caldwell, 1981; Porter et al., 1976). However, organisational commitment varies over time. It needs to be nurtured and maintained, as a decline in the level of organisational commitment often occurs immediately prior to a person leaving an organization (Porter et al., 1976). The condition of the organization is also an important factor. From responses of women employees in the Australian construction industry, it is found that job involvement, supervisory support, and perception of the organizational diversity climate are significantly correlated with respondent organizational commitment (Lingard \& Lin, 2004). Saridakis et al. (2018) find that increased job satisfaction (JS) leads to enhanced organizational commitment (OC), and the vice versa, suggesting that JS and OC are likely to be reciprocally related. A recent analysis of data concerning 3,821 employees of 130 Korean companies, for example, found a significant dependency between organisational commitment and the financial performance of the company (Chun et al., 2013).

\section{Work Stress}

Work stress is a measure of the reaction a person has to any mismatch between organisational expectations and actual personal abilities in fulfilling job tasks (Tennant, 2001). Stress has 
become an important consideration in organisational management due to the increasing prevalence of psychological disorders in the workplace (Tennant, 2001), and can also lead to a range of related physiological health issues, such as raised blood pressure (Matthews et al., 1987). Such mediating factors as peer support complicate the measurement and impact of work stress. For example, support from co-workers has been shown to decrease the level of work stress and improve job performance (AbuAlRub, 2004) even when the level of base stress remains high (Hon, 2013). Edwards (1996) also critically links demands-abilities fit with levels of tension and uses it as a direct measure of the level of construction worker stress to predict task performance (Leung et al., 2010). Construction personnel under prolonged job stress are more prone to making errors which can eventually lead to fatal construction accidents, while good working environments and individual's coping ability are dilutions to the burnout results (Poon et al., 2013).

\section{Job Satisfaction}

Job satisfaction is a response to any discrepancy between available and desired resources and opportunities (Nerkar et al., 1996; Wanous \& Lawler, 1972) and occupies an appreciable proportion of behavior research in management (Organ, 1988b). Brayfield \& Crockett's (1955) study of how job satisfaction influences job performance, for instance, dates back to the human relations movement of the 1930's; numerous studies (e.g., Edwards, 1996; Pervin, 1987; Rounds et al., 1987) show the needs-supplies fit is also an effective indicator of satisfaction, along with such related context variables as organisational learning climate (Egan et al., 2004); Organ \& Ryan's 1995) meta-analysis of 55 OCB studies concludes that job satisfaction, along with job attitudes, is a robust predictor of OCB; while Tett \& Meyer 
(1993) find that job satisfaction is also a strong predictor of organisational commitment and employee turnover.

\section{Job Performance}

Job performance is a central construct in the study of occupational psychology (Austin \& Villanova, 1992; Campbell et al., 1990; Murphy \& Cleveland, 1995) and represents a fundamental aspect of organisational management practice (Judge et al., 2001). Theories of job performance go back to the very earliest development work in management science pioneered by 'Taylorism', which established such foundational techniques as standardization and synthesis to increase the efficiency of the production process and the productivity of workers. 'Fordism' later built on 'Taylorism' by applying these techniques to assembly lines to combine high productivity from mechanization with higher wages to motivate workers. Early considerations focused on such technical factors as sequencing and specialization, while attention more recently has turned to contextual performance in terms of organisational citizen behavior and prosocial organisational behavior as key factors influencing effective job performance at the organisational level (Borman \& Motowidlo, 1997), and labor relations and organization culture to drive performance improvement (Bonanno \& Constance, 2001).

Of especial importance to our theme is Viswesvaran and Ones's (2000), later endorsed by Rotundo \& Sackett (2002), review of research into job performance, which establishes three particularly useful perspectives of individual task performance, organisational citizen behavior (job performance as the behavior of an individual within an organization), and the counter-productive work behavior of individuals, as elaborated in the following subsections. 
Task performance measures the extent to which individuals successfully complete the duties specified in their work descriptions, defined as:

the proficiency with which incumbents perform activities that are formally recognized as part of their jobs - activities that contribute to the organization's technical core either directly, by implementing a part of its technological process, or indirectly, by providing it with needed materials or services (Borman \& Motowidlo, 1993; Judge et al., 2001; Viswesvaran and Ones, 2000).

Task performance is a key focus for earlier studies of job performance (Borman \& Motowidlo, 1997; Conway, 1999; Van Scotter \& Motowidlo, 1996) and continues to be included in a broad range of studies to this day (Cheng et al., 2007). However, task performance is now well recognized as just one of multiple categories relevant to the assessment of job performance overall.

\section{Organisational Citizen Behavior}

Job performance is influenced by the organisational commitment of an employee (Angle \& Perry, 1981; Mowday et al., 1974; Steers, 1977). In particular, the voluntarily commitment of employees to their organization, independent of any expectation of reward - organisational citizen behavior (OCB) (Podsakoff et al., 2009) - is significant (Mathieu \& Zajac, 1990; Iverson, 1996). Turnipseed \& Rassuli (2005), for example, studied the relationship between 
OCB and job performance empirically with 10 managers and 125 manufacturing workers, finding the best performing workers have a higher OCB and a strong connection between OCB and performance.

OCB includes such activities as assuming non-assigned job responsibilities, spontaneous innovation, being generally helpful to colleagues (Eisenberger et al., 1990), and general compliance with organisational rules and expectations (Smith et al., 1983). Elsewhere OCB has been classified across five dimensions of sportsmanship, altruism, commitment, courtesy, and civic virtue (LePine et al., 2002; Organ, 1988a). Of these, the empirical work of Podsakoff et al. (1997) demonstrates the especially important influence of sportsmanship and altruism on performance, although a later extensive literature review by LePine et al. (2002) concluded that altruism, commitment, courtesy, and civic virtue may also be highly correlated.

Other studies examine the relationship between OCB and other factors. For example, Eisenberger et al. (1990) draws on a range of OCB behaviors to demonstrate a positive correlation between OCB and perceived level of organisational support. Murphy et al. (2002) show that job OCB and participation behavior correlate significantly with job satisfaction. Chughtai (2008) finds both OCB and in-role job performance to be positively correlated with job involvement. Markos \& Sridevi (2010) demonstrate that employee engagement based around OCB also promotes job satisfaction and employee commitment.

\section{Counterproductive Work Behavior}

Counterproductive work behavior (CWB) is a facet of job performance (Sackett, 2002) in which behavior intentionally harms legitimate corporate interests (Dalal, 2005). Such behaviors mainly comprise theft and related behaviors, destruction of property, misuse of 
information, misuse of time and resources, unsafe behavior, poor attendance, poor quality work, alcohol and drug use, inappropriate verbal actions, and inappropriate physical actions (Gruys \& Sackett, 2003; Sackett \& Wanek, 1996). While CWB items and categories are generally positively related, multidimensional scaling analysis suggests that CWB categories vary in two dimensions of interpersonal-organisational, which includes property and equipment sabotage, substance abuse and deliberate misuse of time (Sackett \& Wanek 1996); and task relevance (Gruys \& Sackett, 2003). CWB has also been found to share a number of antecedents in common with OCB and task performance (Fox et al., 2012; Miles et al., 2002), most particularly in terms of job satisfaction and organisational justice (Dalal, 2005). Other causes of CWB include job demands and job resources (Balducci et al., 2011), workplace stress (Fox et al., 2001), perceived unfairness (Cohen-Charash \& Mueller, 2007), personality (Bowling \& Eschleman, 2010), boredom (Bruursema et al., 2011), and narcissism (Penney \& Spector, 2002).

\section{The Job Performance of Construction Professionals}

The most prominent construction management research journals are considered by many to be Automation in Construction (AUTCON); Building and Environment (B\&E); Construction Management and Economics (CM\&E); Engineering, Construction and Architectural Management (ECAM); the International Journal of Project Management (IJPM); and the ASCE's Journal of Construction Engineering and Management (JCEM) and Journal of Management in Engineering (JME). Using the key search term 'job performance', 227 articles were identified and obtained from the seven journals listed. A further individual 
investigation of each article identified a final cohort of 13 articles where the key theme of the research is the job performance of construction professionals such as architects, engineers, quantity surveyors, and project managers.

Mustapha \& Noaum (1998) categorize the factors influencing job performance as personal, environmental, and organisational, and based on job conditions and project characteristics. However, the final 13 articles considered were found to give far greater emphasis on the personal factor (with such aspects as knowledge, experience, personality, stress, and job satisfaction). For this reason, job performance issues not particular to the personal factor are simply grouped together as contextual factors.

\section{Individual Factors}

Personality traits

Early work by Carr et al. (2002) investigated the relationship between the personality traits of construction professionals and job performance. The study involved 85 project managers from 5 professional organizations in the United States, specializing in engineering, architectural, and construction management services. The project managers comprise engineers (58\%), architects $(22 \%)$, construction administrators $(14 \%)$, and surveyors $(6 \%)$. The study required respondents to complete a Critical Project Success Factors (CPSF) questionnaire, as well as the standard long-form Myers-Briggs Type Indicator (MBTI, FormM) for personality measurement. The results indicate that a range of individual personality traits determines job performance. For example, construction professionals with a personality preference for 'judging' (that is, to gather only sufficient information to make a decision to act) perform better than those with a preference for 'perception' (that is, being finely tuned to changing situations and alert to new developments which may require a change in strategy) when preparing contract documentation. In contrast, construction professionals with a 
preference for perception tend to outperform those with a preference for judging during the project planning stage.

Psychological empowerment

Tuuli and Rowlinson (2009) use Hierarchical Linear Modeling (HLM) to analyses the questionnaire responses of 380 project management staff from 115 organizations (52 contractor, 34 client, and 29 consultant) in Hong Kong. Of the organizations initially classified as client organizations, 19 respondents from 11 organizations were working in dual roles as both client and consultant. This study involved a battery of measures, including psychological empowerment (Spreitzer, 1995), employee in-role behaviors (Williams \& Anderson, 1991), an adapted version of contextual performance behaviors (Van Scotter \& Motowidlo, 1996), opportunity to perform (Spector \& Jex, 1998), intrinsic motivation (Hackman \& Oldham, 1976), and ability to perform (Podsakoff et al., 1993). The results show that psychological empowerment has not only direct and positive performance consequences, but also indirect effects mediated by intrinsic motivation, opportunity to perform, and ability to perform.

Behavioral

Also noted are some significant differences between the contractor and client/consultant results. Ahadzie et al. (2008a) carried out a questionnaire survey of 69 registered project managers in Ghana, involving 64 behavioral measures against 15 performance variables. The performance variables were combined into a single variable using factor analysis, and used in a regression analysis of the behavioral measures. The study shows that knowledge of project management techniques, the ability to manage time effectively, problem solving skills and relationship management are significant predictors of job performance. Contextual behaviors in general accounted for $24 \%$ of the variance and task performance behaviors $50 \%$. This 
finding is very much in line with the work of Borman \& Motowidlo (1993) and subsequently Conway (1999), in which contextual behaviors were found to account for $30 \%$ and task performance behaviors over $50 \%$ of the variation.

Stress

The effect of work stress on the individual performance of construction professionals has been the subject of several studies. For example, a questionnaire survey of 177 professional estimators in Hong Kong examined the impact of stress on estimator performance (Leung et al. 2005b). The survey rated the level of stress based on 17 aspects of personal, interpersonal, and organisational stress factors. Correlation analysis, regression analysis, and structural equation modelling were then used to examine the relationships between stress and various aspects of job performance to develop a causal structural model. This model shows that stress is both a root cause of poor estimation performance (creating and resulting from weak interpersonal relationships, unfamiliarity with the organization and ineffective processes), and simultaneously a direct benefit to estimating performance.

A similar survey of 95 professional cost engineers in Hong Kong examined the relationship between stress-coping behaviors and estimation performance outcomes using correlation and multiple regression (Leung et al., 2006). This study showed that the performance of less experienced cost engineers deteriorated when their stress-coping behavior focused on self-control strategies, while emotional expression had a positive effect. In contrast, emotional expression had a negative impact on the job performance of more senior cost engineers, where the most positive outcome required better instrumental support and preparatory action.

In another study of 110 cost engineers in Hong Kong, the complicated relationships between stress, commitment, and performance were analyzed by correlation analyses and 
regression modelling (Leung et al., 2015). The results of this study indicate that both stress and commitment affect performance (Leung et al., 2015). In this study, stress comprises both subjective and objective stress. Objective stress was found to influence career commitment with an inverted U-shaped relationship, and an increased level of commitment was found to improve estimating accuracy. Subjective stress has a straight linear relationship to both career commitment and continuance commitment, with an equivalent impact on estimating performance.

Leung et al. (2011) also explore the nexus between stress and performance for project management consultants, using structural equation modelling to demonstrate that job stress has a strong negative effect on task performance. Whilst the potential mediating effect of career commitment was untested, the findings more generally indicate that a proactive personality is a significant factor affecting job performance.

Job satisfaction

A final and related issue here concerns job satisfaction. In a small study by Ling \& Loo (2013), for instance, a correlation analysis of structured questionnaire data collected from 32 construction project managers in Singapore revealed that both individual job characteristics (such as the level of autonomy) and individual personality characteristics (such as relevant knowledge and skills) affect job satisfaction along with job performance.

\section{Contextual Factors}

A questionnaire survey by Pheng \& Chuan (2006) of 124 Singapore contractors and consultants examines the importance of the working environment on job performance. The working environment is categorized in terms of job-related factors, such as salary, job 
satisfaction, job security, working hours, and availability of information; project-related factors, such as the project environment, project size, time availability, complexity of project, team relationships, materials, suppliers, and duration of project; and organisational-related factors, such as company size, level of authority, and type of client. Overall, every factor except working hours and company size significantly affects project performance, with team relationships ranked as the most important. There are also significant differences between contractors and project managers, especially in terms of project-related factors, to which contractors are typically more susceptible

\section{Conceptual Models}

A number of studies focus on how performance can most usefully be conceptualized in the immediate context of construction. Ahadzie et al. (2008b) propose a competency-based model of performance based on their empirical study of project manager consultants in Ghana. The model effectively separates and distinguishes between task performance behaviors and contextual performance behaviors. A study by Dainty et al. (2005) also used a theoretical model based on the core competencies of construction project managers to predict job performance. The study found self-control and team leadership to be the two most critical competency predictors of successful project management performance. Liu \& Fellows (2008) investigate quantity surveyors in Hong Kong using an OCB lens, finding an orientation that favors individualism over collectivism to negatively impact on job performance.

\section{Conclusion}

The overview of literature specific to the job performance of construction professionals identifies three particular themes: context versus individual perspectives, psychological 
factors (such as work stress and job satisfaction), and the development of conceptual models. Also highlighted are a number of potentially important limitations of previous research. For example, previous studies typically use regression analysis to determine the significance of the relationships between potential predictors and a dependent variable of interest. Such an approach invariably fails to consider possible mediating or moderating impacts caused by interactions between the predictors themselves. Recently developed statistical methods, such as structural equation modelling (SEM), offer a more effective approach when more complex interactions are present (Xiong et al., 2015b).

The factors claimed to predict performance are also sometimes confused with just measures of performance. For example, in a study of engineering and architectural consultants in design-build projects, Ling (2002) tests the extent to which, and how a mix of, hard attributes (such as job knowledge) and soft attributes (such as commitment) affect job performance, finding that job performance (production of design drawings) is predicted by the speed at which the drawings are produced. The claimed causal link, however, may have more to do with how performance is defined and measured, than it has with how performance can actually be influenced and improved. Moreover, several studies fail to match the scope of the factors being measured. All factors need to be at the same level of scope, or cross-level analysis is required. For example, Ling \& Loo (2013) measure job performance at the project level and personal satisfaction at the individual level within the same study.

\section{Towards an Integrated Conceptual Model of the Job Performance of Construction Professionals}

This research extends the P-E fit model to the prediction and assessment of job performance specific to construction professionals. In doing this, the starting point is the diverse theories used to date to evaluate and improve the job performance of employees in 
general, including human resource management, personality, competency, motivation, selfdetermination, work adjustment, and P-E fit itself (Greguras \& Diefendorff, 2009; Schneider, 2001). From this, we identify the central role of the three P-E fit assessments of organizational commitment, work stress, job satisfaction, and their linkages with the individual attributes of job knowledge, abilities, and skills, and organisational aspects of support, politics, and learning climate. This is then placed in a stimulus-assessmentperformance arrangement that, although intended primarily for construction professionals, provides a new common conceptual integrative framework as a basis for research and practice in organisational behavior and human resource management specific to job performance for employee behavior research more generally.

\section{Integrated Conceptual Framework Proposal}

Broadening the scope of P-E fit to relate to employee behavior research more generally involves the potentially reciprocal relationships between person, environment, and job performance. This locates P-E fit as a mediating factor in the dynamics of such relationships, similar to the concept of an organism factor in the Stimulus-Organism-Response (S-O-R) adaptation of the stimulus-response (S-R) model by Mehrabian \& Russell (1974), the development of which helps to distinguish the critical role judgement and analytical ability can play in the relatively mechanical (S-R) relationship. In the context of employee behavior

research, the stimulus part of the equation compares most directly with organisational environment and personal behavior. The response part is then job performance. Given that PE fit provides a means of assessing the interactions between organisational environment, personal behavior, and job performance, it follows that research might usefully articulate from a framework that adopts an S-O-R characterization. 
Fig. 2 shows how this can be organized, with environmental and individual factors affecting job performance mediated (fully or partially) by P-E fit assessments in the form of a stimulus-assessment-performance (S-A-P) configuration. The S-A-P model, therefore, links environmental factors, individual characteristics, P-E fit assessments, and job performance.

$$
<<\text { insert Fig. } 2 \text { here }>>
$$

In the proposed framework, the more generic, individual factors (needs, abilities, and characteristics) previously associated with the individual difference approach to employee selection (Schneider 2001) are replaced with job knowledge, skills, and cognitive ability. Hunter's (1986) comprehensive review of the literature measuring the relationship between general cognitive ability and job performance in various jobs, finds that cognitive ability affects job performance unequivocally through job knowledge and skills. Dilchert et al. (2007) find that individual cognitive ability also mediates CWB, as workers with higher cognitive abilities tend to consider their actions before engaging in counterproductive activities. An investigation into the impact of skills on job performance also found that a deficiency in job skills leads to lower job performance (Wade \& Parent, 2002), while Meier $\&$ Spector (2013) show there is a reciprocal nexus between stressful working conditions and CWB.

The proposed framework also replaces the more generic attributes, demand and supply factors (previously associated with the environment) with key organisational factors. As pointed out by Schneider (2001), many P-E fit studies are preoccupied with identifying commensurate measures for $\mathrm{P}$ and $\mathrm{E}$. By using three assessments as indirect measures to reflect P-E fit, the S-A-P model is able to examine the effects of such organisational factors as organisational support, organisational politics, and organisational learning climate. Smith et al. (1983), for instance, found a positive relationship between job satisfaction and 
employee altruistic behaviors; Eisenberger et al. (1986) found individual absenteeism to be negatively correlated with organisational support; while a meta-analysis of 70 studies related to organisational support found employees rated fairness, supervisor support, organisational rewards, and enjoyable working conditions especially important factors (Rhoades \& Eisenberger, 2002). Further, consistent with the norm of reciprocity, Rousseau (1990) found that employees use hard work and job loyalty to reciprocate with such organisational support as fair career advancement.

The political nature of any working environment is less of a concept and more of a fact (Ferris \& Kacmar, 1992) - a business company being a political coalition where decisions are made as much by negotiation and bargaining as by the market (March, 1962). Also driving this perception of organisational politics at play is a natural tendency to assign humanlike characteristics to organizations (Eisenberger et al., 1986; Rhoades \& Eisenberger, 2002). On the other hand, while political behavior is often associated with the higher levels of an organization (Ferris \& Kacmar, 1992), the focus for lower level employees is more in terms of lack of power and control to influence job satisfaction (Gandz \& Murray, 1980).

\section{Conclusion}

The job performance of construction professionals is a product of the interaction between person and environment. In addition to objective environmental factors and individual differences, psychological reactions (defined as P-E fit assessments in this study) are also critical. From a cross-sectional perspective, the study assumes that stimulus factors from the environment and individual differences affect job performance via the mediation effects of PE fit assessments. In doing this, the study makes several contributions: 
1. The broad range of potentially factors hampering the development of a common conceptual model that articulates between individual job performance and the specifics of the project context are greatly reduced by adopting the well-established framework of P-E fit theory. As shown in Fig. 1, the P-E fit assessments are also simplified and incorporated as mediating factors in the P-E dynamic. The importance of this contribution is even more evident in the integrated conceptual model in Fig. 2, where the same P-E fit assessments already incorporated as intrinsic mediating factors in Fig. 1 are used to link the P-E factors to a simplified measure of job performance.

2. The introduction of an appropriate moderator has also been shown to substantially mitigate the increased risk associated with an initial reduction of the factors involved when seeking to resolve complex and unsettled problems in general (Xiong et al., 2015b). Reducing the number of factors identified in the literature reduces the potentially significant risks to just three principal categories for each person: the environment, assessment, and performance representation. This means that, for example, having a moderator reduces the problems associated with the consistency with which each category is defined and applied across different studies and organizations at such a metalevel, or prospects of the principal categories excluding or cloaking the impact of individual factors that would otherwise be significant. Moreover, this contribution also avoids the possibility of robust categories being established and becoming resistant to change and/or the introduction and consideration of new and differentiated factors in the future, with the added complexities of internal dynamics within each of the broad categories having the potential to create confounding relationships between categories.

3. Following Schneider (2001), the focus for the individual is on knowledge, skills, and ability, and there is substantial support for the significance of these three factors in driving the behavior of employees (Hunter, 1986; Wade \& Parent, 2002; Dilchert et al., 
2007; Meier \& Spector, 2013). Therefore, the potential risk associated with this particular contribution is minimal given the extent and consistency of its use in previous studies.

4. A significant contribution of the model is its use of indirect measures (organisational measures strongly correlated with the common assessment factors), which enables it to also be applied in a reverse, diagnostic, capacity. In this way, for example, the same model can be used to identify corrective approaches and management strategies. For instance, the options to improve employee performance using particular forms of improved organisational support.

5. The focus of the organisational factors on indirect measures renders a commensurate approach with person factors more viable, as the organisational factors are selected based on the strength of their demonstrated relationship with the key P-E fit assessment factors of organisational commitment, work stress, and job satisfaction, due to the wellestablished fact that these three assessment factors correlate strongly with organisational support (Rousseau, 1990; Smith et al., 1983; Eisenberger et al., 1986; Rhoades \& Eisenberger, 2002), politics (Eisenberger et al., 1986; Rhoades \& Eisenberger, 2002; Ferris \& Kacmar, 1992; Gandz \& Murray, 1980), and learning (Hellriegel \& Slocum, 1974; Mikkelsen \& Grønhaug, 1999; Argyris \& Schön, 1978; Egan et al., 2004). Once again, the consistent strength of relationships evident in previous studies renders this choice of factors relatively secure.

6. The process of simplification underpinning the integrated conceptual model contributes to providing an initial, operable framework for studies (both past and future), which would otherwise make the problem of job performance improvement in the construction industry likely remain intractable in addressing the inertia involved. 
Being an exploratory study, the implications for research and practice are mainly concerned with the future, in that:

1. combining P-E fit theory using an S-O-R paradigm equivalent, the resulting stimulusassessment-performance, or S-A-P, provides an integrated framework that can both interpret previous studies and underpin future research agendas and propositions, such as in the development of the detailed metrics involved, while the moderating nature of the PE fit assessment component means that the model can act as a base reference and help avoid the potential for pseudo-causation conclusions.

2. the introduction of the common mediating layer between person and environment as well as between the stimulus of P-E and response of job performance, and the choice of a common layer based on P-E fit assessment factors not only accommodates previous studies but also lays a coherent foundation for future studies. It is a 'big picture' framework to understand employee behavior and to shape future employee behavior research. Although the moderating layer also represents the greatest source of risk, there are many other moderating variables for possible inclusion as factors in the model, ranging across gender, age, industry, country, culture, job alternatives in the market, reward contingency, and individual learning style.

3. a particular opportunity with the integrated form of this proposed model is the capacity to generate and test new research propositions concerning factors and relationships. For example: the proposition that job satisfaction, as an indicator of needs-supplies (N-S) fit, positively affects job performance; that organisational commitment, an indicator of supplementary fit, positively affects job performance; and/or that work stress, as an indicator of demands-abilities (D-A) fit, negatively affects job performance. 
4. There are further possibilities to frame research more effectively. By considering time lags (e.g. seasons, years), for instance, the model has the potential to offer insights into how job performance and P-E fit assessments may influence future perceptions of emerging stimulus factors at both personal and organisational levels. Similarly, by controlling the introduction of new variables/concepts, an expansion and/or adaptation of the model to address such other outcomes as turnover intention is entirely feasible.

5. further refinements are also possible, for example to take further account of the exigencies of projects as temporary organizations, the proposed model provides an initial framework for future studies of the job performance of construction professions in revealing how organisational factors and individual differences affect job performance because of the mediating role of P-E fit assessments; empirical tests could inform whether this is a fully or partially mediated function. Similarly, is the identification and measurement of both the antecedents and effects of P-E fit, which has vital implications, especially in exploring the effects of feedback with time lags. Likewise, is the identification of the most effective moderator in these relationships and within the specific contexts of industry, organization, or operational unit. That the moderators might vary under different conditions of culture (Chuang et al., 2015), means that examining the dynamics within the model itself should provide a further significant contribution to the body of knowledge.

\section{Acknowledgements}

The first author is financially supported by a QUT HDR Sponsorship from the research project "BER-CAM" funded by the Commonwealth of Australia represented by the Department of Education. 


\section{Declaration of interest}

There are no conflicts of interest to declare.

\section{References}

AbuAlRub, R. F. (2004). Job stress, job performance, and social support among hospital nurses. Journal of Nursing Scholarship, 36, 73-78.

Ahadzie, D., Proverbs, D., \& Olomolaiye, P. (2008a). Model for predicting the performance of project managers at the construction phase of mass house building projects. Journal of Construction Engineering and Management, 134(8), 618-629.

Ahadzie, D. K., Proverbs, D. G., \& Olomolaiye, P. (2008b). Towards developing competency-based measures for construction project managers: Should contextual behaviours be distinguished from task behaviours? International Journal of Project Management, 26, 631-645.

Angle, H. L., \& Perry, J. L. (1981). An empirical assessment of organizational commitment and organizational effectiveness. Administrative Science Quarterly, 1-14.

Argyris, C., \& Schön, D. A. (1978). Organizational learning: A theory of action perspective. Addison-Wesley Reading, MA.

Austin, J. T., \& Villanova, P. (1992). The criterion problem: 1917-1992. Journal of Applied Psychology, 77(6), 836.

Australian Constructors Association (2014). Major infrastructure projects: costs and productivity issues, Sydney: Deloitte Access Economics. 
Balducci, C., Schaufeli, W. B., \& Fraccaroli, F. (2011). The job demands-resources model and counterproductive work behaviour: The role of job-related affect. European Journal of Work and Organizational Psychology, 20(4), 467-496.

Becker, H. S. (1960). Notes on the concept of commitment. American Journal of Sociology, $32-40$.

Bonanno, A., \& Constance, D. H. (2001). Globalization, Fordism, and Post-Fordism in agriculture and food: A critical review of the literature. Culture and Agriculture, 23, 1-18.

Borman, W.C., \& Motowidlo, S. J. (1993). Expanding the criterion domain to include elements of contextual performance. Personnel Selection in Organizations, 71, 98.

Borman, W. C., \& Motowidlo, S. J. (1997). Task performance and contextual performance: The meaning for personnel selection research. Human Performance, 10, 99-109.

Bowen, P., Edwards, P., \& Lingard, H. (2012). Workplace stress experienced by construction professionals in South Africa. Journal of Construction Engineering and Management, 139(4), 393-403.

Bowen, P., Edwards, P., \& Lingard, H. (2013a). Workplace stress among construction professionals in South Africa: The role of harassment and discrimination. Engineering, Construction and Architectural Management, 20(6), 620-635.

Bowen, P., Edwards, P., Lingard, H., \& Cattell, K. (2013b). Predictive modeling of workplace stress among construction professionals. Journal of Construction Engineering and Management, 140(3), 04013055.

Bowen, P., Edwards, P., Lingard, H., \& Cattell, K. (2013c). Workplace stress, stress effects, and coping mechanisms in the construction industry. Journal of Construction Engineering and Management, 140(3), 04013059. 
Bowen, P., Edwards, P., Lingard, H., \& Cattell, K. (2014a). Occupational stress and job demand, control and support factors among construction project consultants. International Journal of Project Management, 32(7), 1273-1284.

Bowen, P., Govender, R., \& Edwards, P. (2014b). Structural equation modeling of occupational stress in the construction industry. Journal of Construction Engineering and Management, 140(9), 04014042.

Bowen, P., Govender, R., Edwards, P., \& Cattell, K. (2014c). Workplace stress in the construction industry: An explanatory model. RCOM A, 331.

Bowling, N. A., \& Eschleman, K. J. (2010). Employee personality as a moderator of the relationships between work stressors and counterproductive work behaviour. Journal of Occupational Health Psychology, 15(1), 91.

Brayfield, A. H., \& Crockett, W. H. (1955). Employee attitudes and employee performance. Psychological Bulletin, 52, 396.

Bretz, J. R. D., \& Judge, T. A. (1994). Person-organization fit and the theory of work adjustment: implications for satisfaction, tenure, and career success. Journal of Vocational Behaviour, 44, 32-54.

Bruursema, K., Kessler, S. R., \& Spector, P. E. (2011). Bored employees misbehaving: The relationship between boredom and counterproductive work behaviour, Work and Stress, 25(2), 93-107.

Busby, J. S., \& Zhang, H. (2008). The pathogen construct in risk analysis. Project Management Journal, 39(3), 86-96.

Business \& Enterprise Committee (2008). Construction matters: Ninth Report of Session 2007-08, Volume I, HC 127-I, London: The Stationery Office Limited. 
Campbell, J. P., McHenry, J. J., \& Wise, L. L. (1990). Modeling job performance in a population of jobs. Personnel Psychology, 43(2), 313-575.

Caplan, R. D. (1987). Person-environment fit theory and organizations: Commensurate dimensions, time perspectives, and mechanisms. Journal of Vocational Behaviour, 31, $248-267$.

Carr, P. G., De La Garza, J. M., \& Vorster, M. C. (2002). Relationship between personality traits and performance for engineering and architectural professionals providing design services. Journal of Management in Engineering, 18, 158-166.

Cattell, K., Bowen, P., \& Edwards, P. (2016). Stress among South African construction professionals: a job demand-control-support survey. Construction Management and Economics, 34(10), 700-723.

Chan, I. Y. S., Leung, M. Y., \& Yu, S. S. W. (2012). Managing the stress of Hong Kong expatriate construction professionals in Mainland China: focus group study exploring individual coping strategies and organizational support. Journal of Construction Engineering and Management, 138(10), 1150-1160.

Chang, K., \& Smithikrai, C. (2010). Counterproductive behaviour at work: an investigation into reduction strategies. The International Journal of Human Resource Management, 21(8), 1272-1288. doi:10.1080/09585192.2010.483852

Cheng, E. W., Li, H., \& Fox, P. (2007). Job performance dimensions for improving final project outcomes. Journal of Construction Engineering and Management, 133(8), 592599. 
Chuang, A., Hsu, R. S., Wang, A.-C., \& Judge, T. A. (2015). Does West fit with East? In search of a Chinese model of person-environment fit. Academy of Management Journal, $58,480-510$.

Chughtai, A. A. (2008). Impact of job involvement on in-role job performance and organizational citizenship behaviour. Journal of Behavioral and Applied Management, 9(2), 169.

Chun, J. S., Shin, Y., Choi, J. N., \& Kim, M. S. (2013). How does corporate ethics contribute to firm financial performance? The mediating role of collective organizational commitment and organizational citizenship behaviour. Journal of Management, 39, 853877.

Cohen-Charash, Y., \& Mueller, J. S. (2007). Does perceived unfairness exacerbate or mitigate interpersonal counterproductive work behaviors related to envy? Journal of Applied Psychology, 92(3), 666.

Construction Task Force (1998). Rethinking construction, London: Department of Trade and Industry.

Conway, J. M., (1999). Distinguishing contextual performance from task performance for managerial jobs. Journal of Applied Psychology, 84(1), 3.

Dainty, A. R., Cheng, M.-I., \& Moore, D. R. (2005). Competency-based model for predicting construction project managers' performance. Journal of Management in Engineering, 21(1), 2-9.

Dalal, R. S. (2005). A meta-analysis of the relationship between organizational citizenship behaviour and counterproductive work behaviour. Journal of Applied Psychology, 90, 1241. 
Darrow, J. B., \& Behrend, T. S. (2017). Person-environment fit is a formative construct. Journal of Vocational Behavior, 103(B),117-131.

Dilchert, S., Ones, D. S., Davis, R. D., \& Rostow, C. D. (2007). Cognitive ability predicts objectively measured counterproductive work behaviours. Journal of Applied Psychology, $92,616$.

Edwards, J. R. (1996). An examination of competing versions of the person-environment fit approach to stress. Academy of Management Journal, 39, 292-339.

Edwards, J. R., Caplan, R. D., \& Van Harrison, R. (1998). Person-environment fit theory. Theories of Organizational Stress, 28, 67.

Egan, T. M., Yang, B., \& Bartlett, K. R. (2004). The effects of organizational learning culture and job satisfaction on motivation to transfer learning and turnover intention. Human Resource Development Quarterly, 15, 279-301.

Eisenberger, R., Fasolo, P., \& Davis-LaMastro, V. (1990). Perceived organizational support and employee diligence, commitment, and innovation. Journal of Applied Psychology, 75, 51.

Eisenberger, R., Huntington, R., Hutchison, S., \& Sowa, D. (1986). Perceived organizational support. Journal of Applied Psychology, 71, 500-507.

Ferris, G. R., \& Kacmar, K. M. (1992). Perceptions of organizational politics. Journal of Management, 18, 93-116.

Follmer, E. (2016). What we do to fit in: personality, coping, and Person-Environment fit. $\mathrm{PhD}$ (Doctor of Philosophy) thesis, University of Iowa. 
Fox, S., Spector, P. E., \& Miles, D. (2001). Counterproductive work behavior (CWB) in response to job stressors and organizational justice: Some mediator and moderator tests for autonomy and emotions. Journal of Vocational Behavior, 59(3), 291-309.

Fox, S., Spector, P.E., Goh, A., Bruursema, K., \& Kessler, S. R. (2012). The deviant citizen: Measuring potential positive relations between counterproductive work behaviour and organizational citizenship behaviour. Journal of Occupational and Organizational Psychology, 85(1), 199-220.

Gandz, J., \& Murray, V. V.(1980). The experience of workplace politics. Academy of Management Journal, 23, 237-251.

Giauque, D., Resenterra, F., \& Siggen, M. (2014). Antecedents of job satisfaction, organizational commitment and stress in a public hospital: A PE Fit perspective. Public Organization Review, 14, 201-228.

Greguras, G. J., \& Diefendorff, J. M. (2009). Different fits satisfy different needs: linking person-environment fit to employee commitment and performance using selfdetermination theory. Journal of Applied Psychology, 94, 465.

Gruys, M. L., \& Sackett, P. R. (2003). Investigating the dimensionality of counterproductive work behavior. International Journal of Selection and Assessment, $11(1), 30-42$.

Hackman, J. R., \& Oldham, G. R. (1976). Motivation through the design of work: Test of a theory. Organizational Behavior and Human Performance, 16(2), 250-279.

Hellriegel, D., \& Slocum, J. W. (1974). Organizational climate: Measures, research and contingencies. Academy of Management Journal, 17, 255-280. 
Hon, A. H. Y. (2013). Does job creativity requirement improve service performance? A multilevel analysis of work stress and service environment. International Journal of Hospitality Management, 35, 161-170.

Huang, J. W., \& Li, Y. H. (2012). Slack resources in team learning and project performance. Journal of Business Research, 65(3), 381-388.

Hunter, J. E. (1986). Cognitive ability, cognitive aptitudes, job knowledge, and job performance. Journal of Vocational Behaviour, 29, 340-362.

Ibbs, W., \& Vaughn, C. (2015). Change and the loss of productivity in construction: a field guide. Tech. rep., The Ibbs Consulting Group.

Iverson, R. D. (1996). Employee acceptance of organizational change: the role of organizational commitment. International Journal of Human Resource Management, 7(1), $122-149$.

Judge, T. A., Thoresen, C. J., Bono, J. E., \& Patton, G. K. (2001). The job satisfaction-job performance relationship: A qualitative and quantitative review. Psychological Bulletin, 127,376 .

Kristof, A. L. (1996). Person-organization fit: an integrative review of its conceptualizations, measurement, and implications. Personnel Psychology, 49, 1-49.

LePine, J. A., Erez, A., \& Johnson, D. E. (2002). The nature and dimensionality of organizational citizenship behaviour: A critical review and meta-analysis. Journal of Applied Psychology, 87, 52-65.

Leung, M. Y., Ng, S. T., Skitmore, M., \& Cheung, S. O. (2005a). Critical stressors influencing construction estimators in Hong Kong. Construction Management and Economics, 23(1), 33-44. 
Leung, M.-Y., Olomolaiye, P., Chong, A., \& Lam, C. C. (2005b). Impacts of stress on estimation performance in Hong Kong. Construction Management and Economics, 23, 891-903.

Leung, M.-Y., Liu, A. M., \& Wong, M. M. K. (2006). Impact of stress-coping behaviour on estimation performance. Construction Management and Economics, 24, 55-67.

Leung, M.-Y., Skitmore, M., \& Chan, Y. S. (2007). Subjective and objective stress in construction cost estimation. Construction Management and Economics, 25(10), 10631075.

Leung, M.-Y., Chan, Y. S., \& Olomolaiye, P. (2008a). Impact of stress on the performance of construction project managers. Journal of Construction Engineering and Management, 134(8), 644-652.

Leung, M.-Y., Chan, Y. S., Chong, A., \& Sham, J. F. C. (2008b). Developing structural integrated stressor-stress models for clients' and contractors' cost engineers. Journal of Construction Engineering and Management, 134(8), 635-643.

Leung, M.-Y., Chan, Y.-S., \& Yuen, K.-W. (2010). Impacts of stressors and stress on the injury incidents of construction workers in Hong Kong. Journal of Construction Engineering and Management, 136(10), 1093-1103.

Leung, M.-Y., Shan Isabelle Chan, Y., \& Dongyu, C. (2011). Structural linear relationships between job stress, burnout, physiological stress, and performance of construction project managers. Engineering, Construction and Architectural Management, $18,312-328$. 
Leung, M.-Y., Bowen, P., Liang, Q., \& Famakin, I. (2014a). Development of a job-stress model for construction professionals in South Africa and Hong Kong. Journal of Construction Engineering and Management, 141(2), 04014077.

Leung, M.-Y., Yu, J., \& Chong, M. L. A. (2015). Effects of stress and commitment on the performance of construction estimation participants in Hong Kong. Journal of Construction Engineering and Management, 142(2), 04015081.

Lewin, K. (1935). Dynamic theory of personality. New York: McGraw-Hill.

Ling, F. Y. Y., \& Loo, C. M. (2013). Characteristics of jobs and jobholders that affect job satisfaction and work performance of project managers. Journal of Management in Engineering, 31(3), 04014039.

Ling, Y. Y. (2002). Model for predicting performance of architects and engineers. Journal of Construction Engineering and Management, 128, 446-455.

Lingard, H. \& Lin, J. (2004). Career, family and work environment determinants of organizational commitment among women in the Australian construction industry. Construction Management \& Economics, 22(4), 409-420.

Liu, A. M., \& Fellows, R. (2008). Behaviour of quantity surveyors as organizational citizens. Construction Management and Economics, 26. 1271-1282.

Love, P. E., Edwards, D. J., \& Irani, Z. (2009). Work stress, support, and mental health in construction. Journal of Construction Engineering and Management, 136(6), 650-658.

March, J. G. (1962). The business firm as a political coalition. The Journal of Politics, 24, 662.

Markos, S., \& Sridevi, M. S. (2010). Employee engagement: The key to improving performance. International Journal of Business and Management, 5(12), 89. 
Mathieu, J. E., \& Zajac, D. M. (1990). A review and meta-analysis of the antecedents, correlates, and consequences of organizational commitment. Psychological Bulletin, 108(2), 171.

Matthews, K. A., Cottington, E. M., Talbott, E., Kuller, L. H., \& Siegel, J. M. (1987). Stressful work conditions and diastolic blood pressure among blue collar factory workers. American Journal of Epidemiology, 126, 280-291.

McKinsey Global Institute (2017). Reinventing Construction: A Route to Higher Productivity. Online at www.mckinsey.com/mgi, Accessed 7/12/2017.

Mehrabian, A., \& Russell, J. A. (1974). An approach to environmental psychology. The MIT Press.

Meier, L. L., \& Spector, P. E. (2013). Reciprocal effects of work stressors and counterproductive work behaviour: A five-wave longitudinal study. Journal of Applied Psychology, 98, 529.

Mikkelsen, A., \& Grønhaug, K. (1999). Measuring organizational learning climate a crossnational replication and instrument validation study among public sector employees. Review of Public Personnel Administration, 19, 31-44.

Miles, D. E., Borman, W. E., Spector, P. E., \& Fox, S. (2002). Building an integrative model of extra role work behaviors: A comparison of counterproductive work behavior with organizational citizenship behavior. International Journal of Selection and Assessment, 10(1-2), 51-57.

Mowday, R. T., Porter, L. W., \& Dubin, R. (1974). Unit performance, situational factors, and employee attitudes in spatially separated work units. Organizational Behavior and Human Performance, 12(2), 231-248. 
Mowday, R. T., Steers, R. M., \& Porter, L. W. (1979).The measurement of organizational commitment. Journal of Vocational Behaviour, 14, 224-247.

Muchinsky, P. M., \& Monahan, C. J. (1987). What is person-environment congruence? Supplementary versus complementary models of fit. Journal of Vocational Behaviour, 31, $268-277$.

Murphy, G., Athanasou, J., \& King, N. (2002). Job satisfaction and organizational citizenship behaviour: A study of Australian human-service professionals. Journal of Managerial Psychology, 17(4), 287-297.

Murphy, K. R., \& Cleveland, J. (1995). Understanding performance appraisal: Social, organizational, and goal-based perspectives. Sage.

Mustapha, F. H., \& Naoum, S. (1998). Factors influencing the effectiveness of construction site managers. International Journal of Project Management, 16(1), 1-8.

Nerkar, A. A., McGrath, R. G., \& MacMillan, I. C. (1996). Three facets of satisfaction and their influence on the performance of innovation teams. Journal of Business Venturing, 11, 167-188.

Ng, S. T., Skitmore, R. M., \& Leung, T. K. (2005). Manageability of stress among construction project participants. Engineering, Construction and Architectural Management, 12(3), 264-282.

O'Reilly III, C. A., \& Caldwell, D. F. (1981). The commitment and job tenure of new employees: Some evidence of postdecisional justification. Administrative Science Quarterly, 26.

Organ, D. W., \& Ryan, K. (1995). A meta-analytic review of attitudinal and dispositional predictors of organizational citizenship behaviour. Personnel Psychology, 48, 775-802. 
Organ, D. W. (1988a). Organizational citizenship behaviour: The good soldier syndrome. Lexington Books/DC Heath and Com.

Organ, D. W. (1988b). A restatement of the satisfaction-performance hypothesis. Journal of Management, 14, 547-557.

Ostroff, C. (1993). Relationships between person-environment congruence and organizational effectiveness. Group and Organization Management, 18, 103-122.

Park, S. (2009). Whole life performance assessment: Critical success factors. Journal of Construction Engineering and Management, 135(11), 1146-1161.

Penney, L. M., \& Spector, P. E. (2002). Narcissism and counterproductive work behavior: Do bigger egos mean bigger problems? International Journal of Selection and Assessment, $10(1-2), 126-134$.

Pervin, L. A. (1987). Person-environment congruence in the light of the person-situation controversy. Journal of Vocational Behaviour, 31, 222-230.

Pheng, L. S., \& Chuan, Q. T. (2006). Environmental factors and work performance of project managers in the construction industry. International Journal of Project Management, 24, 24-37.

Podsakoff, N. P., Whiting, S. W., Podsakoff, P. M., \& Blume, B. D. (2009). Individualand organizational-level consequences of organizational citizenship behaviours: A metaanalysis. Journal of Applied Psychology, 94(1), 122-141. doi: 10.1037/a0013079

Podsakoff, P. M., Ahearne, M., \& MacKenzie, S. B. (1997). Organizational citizenship behaviour and the quantity and quality of work group performance. Journal of Applied Psychology, 82, 262. 
Podsakoff, P. M., MacKenzie, S. B., \& Hui, C. (1993). Organizational citizenship behaviors and managerial evaluations of employee performance: A review and suggestions for future research. Research in Personnel and Human Resources Management.

Poon, S. W., Rowlinson, S. M., Koh, T., \& Deng, Y. (2013). Job burnout and safety performance in the hong kong construction industry. International Journal of Construction Management, 13(1), 69-78.

Porter, L. W., Crampon, W. J., \& Smith, F. J. (1976). Organizational commitment and managerial turnover: A longitudinal study. Organizational Behaviour and Human Performance, 15, 87-98.

Porter, L. W., Steers, R. M., Mowday, R. T., \& Boulian, P. V. (1974). Organizational commitment, job satisfaction, and turnover among psychiatric technicians. Journal of Applied Psychology, 59, 603.

Productivity Commission (2014). Public infrastructure inquiry report no. 71, Canberra: Commonwealth Government of Australia.

Rhoades, L., \& Eisenberger, R. (2002). Perceived organizational support: a review of the literature. Journal of Applied Psychology, 87, 698.

Rotundo, M., \& Sackett, P. R. (2002). The relative importance of task, citizenship, and counterproductive performance to global ratings of job performance: a policy-capturing approach. Journal of Applied Psychology, 87(1), 66.

Rounds, J. B., Dawis, R., \& Lofquist, L. H. (1987). Measurement of person-environment fit and prediction of satisfaction in the theory of work adjustment. Journal of Vocational Behaviour, 31, 297-318. 
Rousseau, D. M. (1990). New hire perceptions of their own and their employer's obligations: A study of psychological contracts. Journal of Organizational Behaviour, 11, 389-400.

Sackett, P. R., \& Wanek, J. E. (1996). New developments in the use of measures of honesty integrity, conscientiousness, dependability trustworthiness, and reliability for personnel selection. Personnel Psychology, 49, 787-829.

Sackett, P. R. (2002). The structure of counterproductive work behaviors: Dimensionality and relationships with facets of job performance. International Journal of Selection and Assessment, 10(1-2), 5-11.

Saridakis, G., Lai, Y., Torres, R. I. M., \& Gourlay, S. (2018). Exploring the relationship between job satisfaction and organizational commitment: an instrumental variable approach. International Journal of Human Resource Management,

DOI: 10.1080/09585192.2017.1423100.

Schneider, B. (2001). Fits about fit. Applied Psychology, 50, 141-152.

Schneider, B., Smith, D. B., \& Goldstein, H. W. (1992). Attraction-selection-attrition: Toward a person-environment psychology of organizations. In W. B. Walsh, K. H. Craik, \& R. H. Price (Eds.), Person-environment psychology: New directions and perspectives (2nd ed.): 61-85. Mahwah, NJ: Erlbaum.

Scott-Young, C., \& Samson, D. (2008). Project success and project team management: Evidence from capital projects in the process industries. Journal of Operations Management, 26(6), 749-766.

Senaratne, S., \& Rasagopalasingam, V. (2017). The causes and effects of work stress in construction project managers: the case in Sri Lanka. International Journal of Construction Management, 17(1), 65-75. 
Smith, C., Organ, D. W., \& Near, J. P. (1983). Organizational citizenship behaviour: Its nature and antecedents. Journal of Applied Psychology, 68, 653.

Spector, P. E., \& Jex, S. M. (1998). Development of four self-report measures of job stressors and strain: interpersonal conflict at work scale, organizational constraints scale, quantitative workload inventory, and physical symptoms inventory.

Spokane, A. R. (1987). Conceptual and methodological issues in person-environment fit research. Journal of Vocational Behaviour, 31, 217-221.

Spreitzer, G. M. (1995). Psychological empowerment in the workplace: Dimensions, measurement, and validation. Academy of Management Journal, 38(5), 1442-1465.

Steers, R. M. (1977). Antecedents and outcomes of organizational commitment. Administrative Science Quarterly, 46-56.

Svejvig, P., \& Andersen, P. (2015). Rethinking project management: A structured literature review with a critical look at the brave new world. International Journal of Project Management, 33(2), 278-290.

Tennant, C. (2001). Work-related stress and depressive disorders. Journal of Psychosomatic Research, 51, 697-704.

Tett, R. P., \& Meyer, J. P. (1993). Job satisfaction, organizational commitment, turnover intention, and turnover: path analyses based on meta-analytic findings. Personnel Psychology, 46, 259-293.

Thomas, H. R. (2012). Benchmarking construction labor productivity. Practice Periodical on Structural Design and Construction, 20(4), art.04014048. 
Turnipseed, D. L., \& Rassuli, A. (2005). Performance perceptions of organizational citizenship behaviours at work: a bi-level study among managers and employees. British Journal of Management, 16(3), 231-244.

Tuuli, M. M., \& Rowlinson, S. (2009.) Performance consequences of psychological empowerment. Journal of Construction Engineering and Management, 135(12), 13341347.

Van Scotter, J. R., \& Motowidlo, S. J. (1996). Interpersonal facilitation and job dedication as separate facets of contextual performance. Journal of Applied Psychology, 81(5), 525.

Viswesvaran, C., \& Ones, D. S. (2000). Perspectives on models of job performance. International Journal of Selection and Assessment, 8, 216-226.

Wade, M. R., \& Parent, M. (2002). Relationships between job skills and performance: A study of Webmasters. Journal of Management Information Systems, 18, 71-96.

Wallace, L., Keil, M. \& Rai, A. (2004). How software project risk affects project performance: An investigation of the dimensions of risk and an exploratory model. Decision Sciences, 35(2), 289-321.

Wanous, J. P., \& Lawler, E. E. (1972). Measurement and meaning of job satisfaction. Journal of Applied Psychology, 56, 95-105.

Westerman, J. W., \& Cyr, L.A. (2004). An integrative analysis of person-organization fit theories. International Journal of Selection and Assessment, 12, 252-261.

Williams, L. J., \& Anderson, S. E. (1991). Job satisfaction and organizational commitment as predictors of organizational citizenship and in-role behaviors. Journal of Management, $17(3), 601-617$. 
Xia, B., \& Chan, A. P. (2012). Measuring complexity for building projects: a Delphi study. Engineering, Construction and Architectural Management, 19, 7-24.

Xiong, B., Skitmore, M., \& Xia, B. (2015a). Exploring and validating the internal dimensions of occupational stress: evidence from construction cost estimators in China. Construction Management and Economics, 33, 495-507.

Xiong, B., Skitmore, M., \& Xia, B. (2015b). A critical review of structural equation modeling applications in construction research, Automation in Construction, 49, 59-70.

Zhu, J., \& Mostafavi, A. (2017). Discovering complexity and emergent properties in project systems: A new approach to understanding project performance. International Journal of Project Management, 35, 1-12. 


\section{Figures}

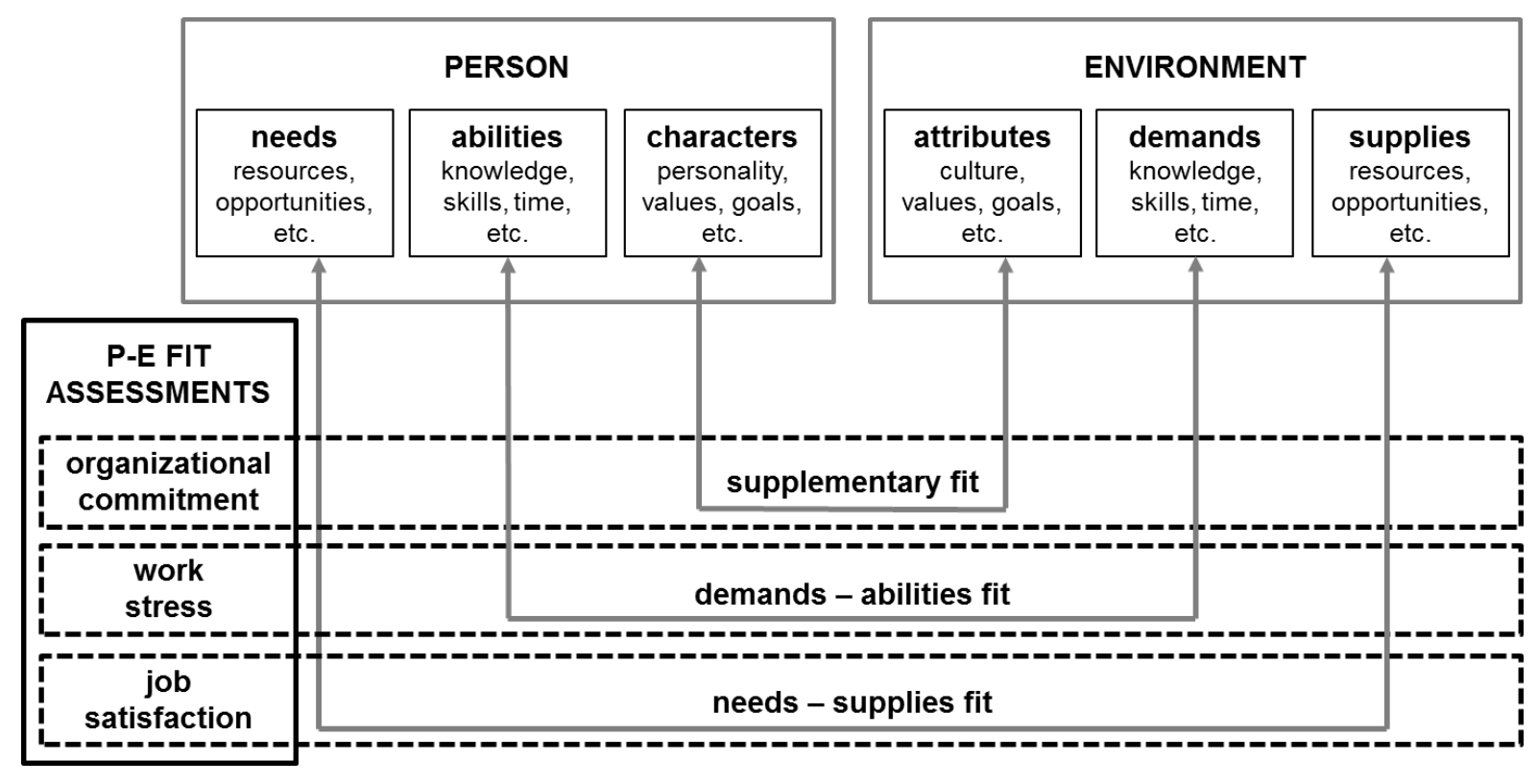

Fig. 1. Overview of the characteristic P-E fit concepts and assessments 


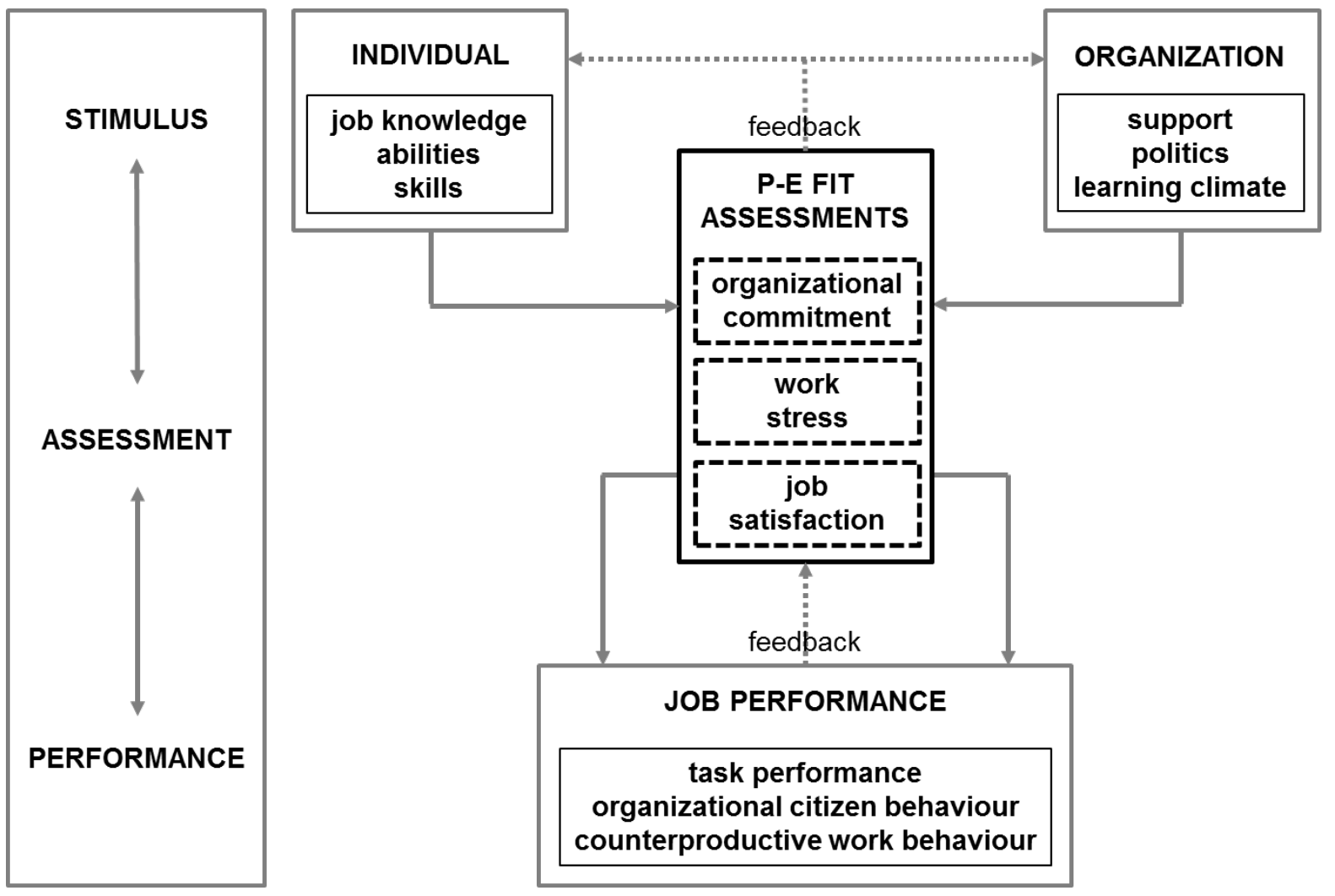

Fig. 2. Conceptual S-A-P model framework. 


\section{Figure captions}

Fig. 1. Overview of the characteristic P-E fit concepts and assessments

Fig. 2. Conceptual S-A-P model framework. 